\title{
The automotive industry in Central Europe: A success?
}

\section{The automotive industry has brought economic growth, but a developmental model based on foreign capital is reaching its limits}

Keywords: automotive industry, Central Europe, development, FDI, sectors, transition

\section{ELEVATOR PITCH}

Central Europe has experienced one of the most impressive growth and convergence stories of recent times. In particular, this has been achieved on the back of foreignowned, capital-intensive manufacturing production in the automotive sector. With large domestic supplier networks and high skill intensity, the presence of complex industry yields many economic benefits. However, this developmental path is now reaching its limits with the exhaustion of the available skilled workforce, limited investments in upgrading and research, and persistent regional inequalities.

\section{KEY FINDINGS}

\section{Pros}

๑ Supplier networks in the automotive industry contribute to job creation and linkages and spillovers stimulate the overall economy.

๑ The automotive industry contributed to Central Europe's economic convergence with the EU core through sophisticated production.

๑ Foreign actors in the sector have helped shape national institutions in terms of education and training and labor market regulation.

- Interconnections with the German economy proved beneficial during the Great Recession.

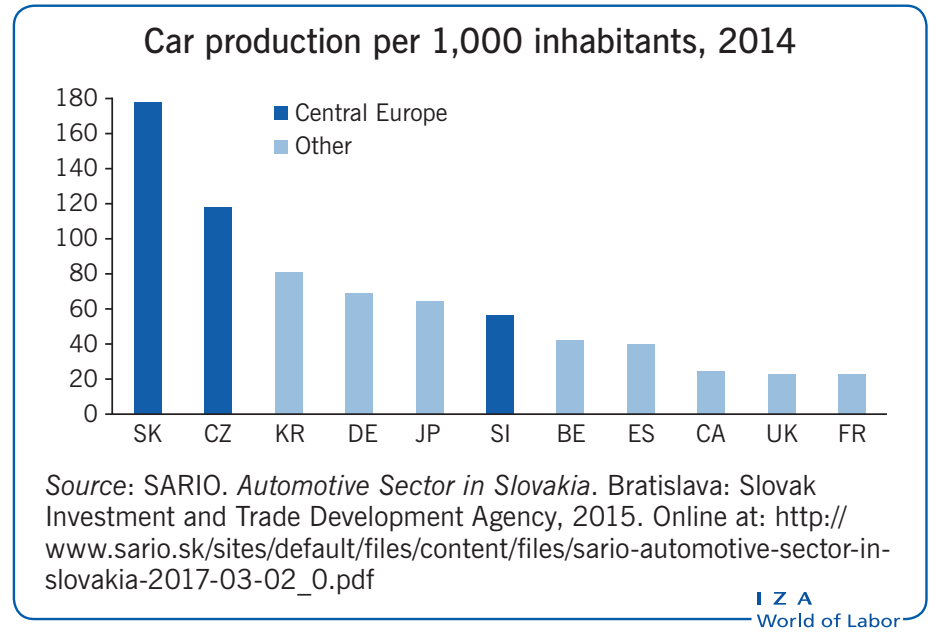

\section{Cons}

- High levels of external dependence and low diversification of production in some countries raise their vulnerability to external shocks.

- While some upgrading has taken place, the share of research and development in employment and value added remains comparatively low.

- Economic development has been uneven and regional inequalities continue to rise.

- The skilled labor supply might soon be fully exhausted.

\section{AUTHOR'S MAIN MESSAGE}

A developmental path in Central Europe based on foreign-owned, export-based manufacturing production has secured relative prosperity through economic growth and the advancement of educational and labor market institutions. In order to sustain prosperity, public policy should focus on increasing the share of research and development in the region, improving national skill bases, and diversifying production structures. A key lesson for developing countries aiming to successfully integrate into global production networks is that active governmental support, favorable human and physical capital endowments, and political stability are necessary. 


\section{MOTIVATION}

Before the 2008-2009 economic crisis, Central Europe-the Czech Republic, Hungary, Slovakia, and Poland (the Visegrad)-experienced one of the most impressive growth and convergence stories of recent times [1], [2]. The regions' development has been based on uniquely high levels of foreign direct investment (FDI) and complex restructuring of the economy after the demise of state socialism [3]. The automotive industry, representing a prime example of complex manufacturing composed of high capital, technology, and skilled labor, became a leading sector in these countries. Its growth was initiated in the very early stages of transition when world-leading companies bought stakes in existing automotive firms. A further wave of greenfield automotive investments followed, especially in the early 2000s, in anticipation of the region's EU accession [4]. By 2014, the Czech Republic and Slovakia had become world leaders in per capita production of light vehicles (see the illustration on page 1), with sizable volumes of passenger cars as well as engines and heavy commercial vehicles produced in Poland and Hungary. In addition to quantity, functional upgrading has secured higher-end production, including expensive and technologically sophisticated car models [5].

Most observers of economic transition in the early 1990s would have been surprised to discover globally integrated, sophisticated manufacturing in Central Europe only a decade and a half later. First, the starting point for such systemic change was characterized by large inefficiencies in the economy, outdated equipment, and dilapidated physical capital. Second, the region experienced a large economic shock at that time, which led to deep recessions, fiscal crises, high inflation, and large structural problems in the labor market. Third, while the transition economies started with relatively similar levels of complex manufacturing production (measured through export shares), their trajectories gradually diverged (Figure 1). A different path based on capital flows into finance and

Figure 1. Complex exports per total exports

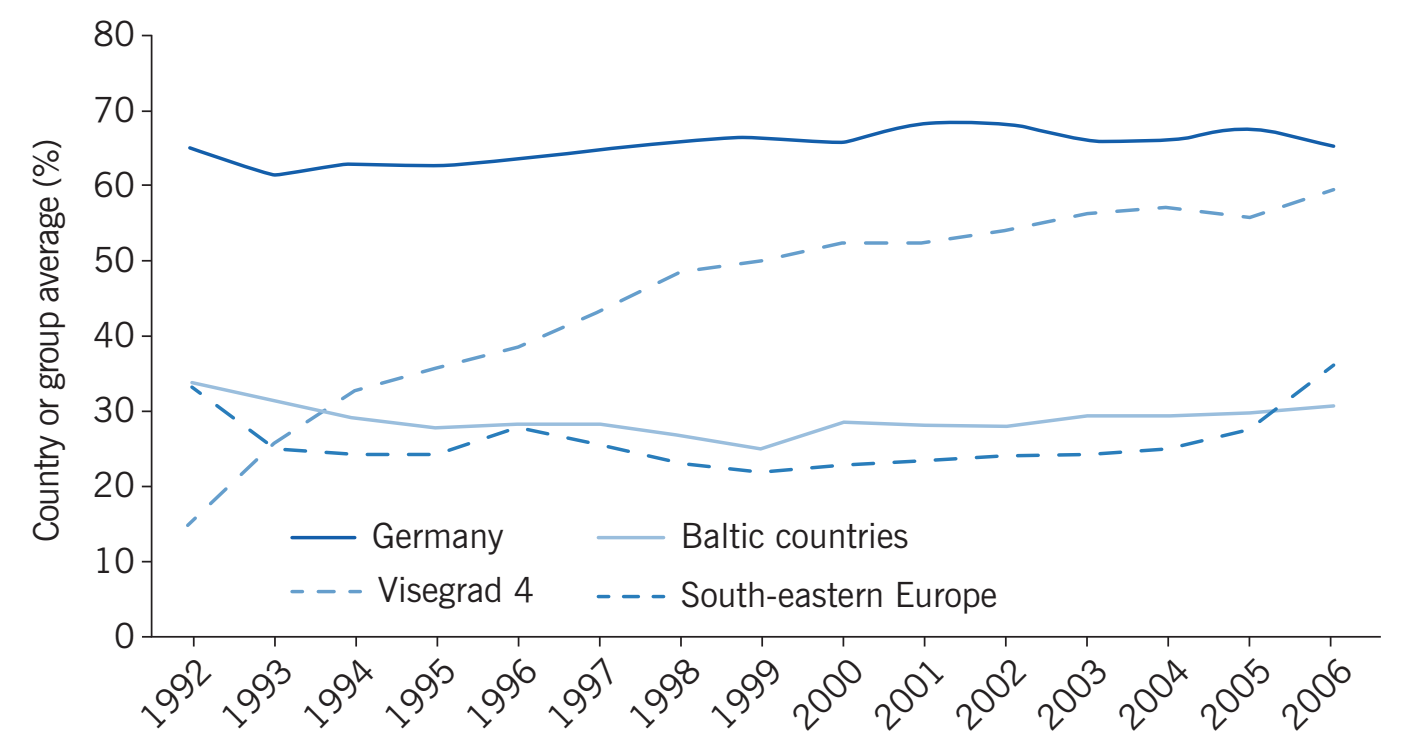

Note: Complex exports are defined as exports in manufacturing belonging to sectors of Standard International Trade Classification Rev 3. Codes 5, 7, 87, and 88. This proxies production intensive in human and physical capital. The Czech Republic, Hungary, Slovakia, and Poland form the Visegrad group of countries.

Source: Author's own calculations based on UN COMTRADE database. Available in Kurekova, L. Commodity Export Structures and the Analysis of Trends in Leading Export Sectors in the European Union. CEU Research Note, 2007. 
services and deindustrialization materialized in the Baltic countries and south-eastern Europe [3].

In several ways, the existing institutional framework with respect to employment, industrial relations, and economic policy more generally has been adapted in Central European countries to sustain the comparative and competitive advantage of complex manufacturing. The 2008-2009 economic downturn showed that these countries (with the exception of Hungary) were more resilient than the Baltic countries, whose developmental model proved less sustainable [3].

From a policy perspective, it is important to identify the key factors behind this particular growth trajectory of Central Europe's development, and the benefits of this developmental model, as well as its limitations and implications for future prosperity.

\section{DISCUSSION OF PROS AND CONS}

\section{What key factors have contributed to the growth of the automotive industry?}

FDI has been the key driver of growth in many transition economies, and in the Visegrad countries in particular [6], [7]. It secured integration into the global supply chains of multinational corporations (MNCs), mainly in the automotive industry but also in electronics sectors, contributing to technological transfer and the provision of necessary capital for upgrading physical infrastructure. Various factors led to the early entry of FDI and then helped secure continued interest in the region well after its accession to the EU in 2004. The theoretical literature discusses market-seeking, efficiency-seeking, resource/factor-seeking, and strategy-seeking motives of foreign capital entry. It appears clear that motivations to invest in Central Europe combined all of those factors and changed over time.

\section{Characteristics of the automotive industry}

The automotive sector is among the largest, most competitive, and most internationalized industries, with high barriers to entry. It is also a classic example of a producer-driven commodity chain. It is characterized by integrated production systems that consist of highly specialized, segment-specific, vertically organized transnational firms. The industry has a high intensity in technology, capital, and skills and is logistically demanding due to lean manufacturing and the system of just-in-time parts delivery. This poses high demands on the quality of a host country's infrastructure. Consequently, lower-income countries without sufficient quality in these underlying inputs lack comparative advantage in the automotive industry. Studies discussing factors that contribute to the development of the automotive industry across the world jointly highlight the crucial role of governmental policies in attracting investment or in providing necessary protection during the industry's early stages.

Source: Gereffi, G. "The organization of buyer-driven global commodity chains: How US retailers shape overseas production networks." In: Gereffi, G., and M. Korzeneiwicz (eds). Commodity Chains and Global Capitalism. Westport, CT: Praeger, 1994; Kureková, L. "Success against all odds? Determinants of sectoral rise and decline in Central Europe." East European Politics and Societies 26:3 (2012): 643-664. 
First, the main reason for foreign investors' initial attraction to complex manufacturing in the region was the availability of relatively skilled, cheap, and docile labor [8]. This advantage was further sustained by an institutional framework that has maintained wage levels below productivity levels. Flexible employment arrangements allowed firms to combine a stable core workforce with a less secure periphery by means of agency employment of domestic as well as foreign workers. This helped leading manufacturing companies withstand fluctuations in demand.

Second, the industrial tradition of Central Europe presented a cornerstone for revitalization and further development of the sector. During state socialism, Central Europe served as the industrial base for processing primary commodities coming from the Soviet Union. This was due to a comparative advantage and manufacturing legacy dating back to the pre-Soviet era. For example, the Škoda factory was set up in Czechoslovakia in the 1920s, while light vehicles, buses, heavy, and military vehicles and engines have a long history of production in Hungary and Poland. In relative terms, the state socialism-era factories in Central Europe were advanced, including having original branding and conducting their own research and development (R\&D). This manufacturing legacy signaled to foreign investors the presence of sufficient human capital and physical capacity to produce complex manufacturing goods [9].

Third, Central Europe's geographic location, including its proximity to Germany, gave strategic significance to firms' initial decisions to enter the region. Furthermore, the prospects of EU accession piqued automotive firms' interest in entering or deepening their presence in the market. While firms initially followed a "build-where-you-sell" strategy, the small size of the Central European market and the relatively unfulfilled expectations of the region's purchasing power caused strategies to shift toward producing for the EU market. Moreover, joining the EU guaranteed political stability and institutional convergence to Western standards [10].

Fourth, governments enacted favorable industrial policy and built up professionalized investment support services to attract and retain foreign investments [11]. In the early 1990s, Visegrad governments opened up to FDI to various extents and at different speeds. More open policies toward foreign capital in Hungary and Poland initially secured comparatively higher levels of FDI relative to Czechoslovakia [4]. The early 2000s was characterized by cut-throat competition between Visegrad countries. In these bidding wars, potential investors clearly held the upper hand, securing generous tax breaks, infrastructural development, and financial support for building greenfield production sites and delivering workforce training [1], [4]. The countries gradually made support more transparent and designed differentiated schemes to attract new firms to less developed regions. After EU accession, state support reoriented to after-investment care, with the aim of embedding and upgrading companies, for example in the form of funding for personnel training and R\&D. This form of financial support was enabled due to the availability of EU structural funds.

As a result of these factors, over the past 25 years, the region has turned into a major automotive cluster, where most leading brands are represented and a rich supplier network covers the Czech Republic, north-western Hungary, western Slovakia, and south-western Poland. While investors' interest temporarily declined during the Great Recession, further entries or expansions of production capacities were announced in 2015 and 2016 in all Visegrad countries. The existing production sites continue to use 
state-of-the-art technology and are highly competitive within their respective automotive consortia.

\section{What are the benefits of this development?}

In retrospect, it is clear that the developmental path based on sophisticated manufacturing production that Central Europe followed secured economic growth, convergence with the EU, and global competitiveness [2]. The most recent significant test was the 2008-2009 economic crisis, which revealed that the Visegrad countries (with the exception of Hungary) were more resilient than the Baltic countries [6]. Several factors underpin this economic performance.

First, due to the technological intensity and complexity of production, the automotive industry (and other capital-intensive industries) generates rich forward and backward linkages. Backward linkages are characterized primarily by the emergence of local supplier networks. Forward linkages are extensions and links to other industries, e.g. textiles, electronics, or transport and logistics [7]. Through backward and forward linkages, additional employment is created and multiplier effects emerge. Moreover, as interlinkages become more entrenched, manufacturers and suppliers become more geographically embedded, making relocation less likely (though still possible). It is through various linkages and spillover effects rather than via corporate taxes that the country-level economic benefits surface [7]. Economies may be further invigorated due to productivity pressures and corporate governance practices that foreign firms exert on domestic firms [1].

Second, skill-intensive production requires a continued supply of well-trained labor. Flagship manufacturers were aware of this, and thus became actively engaged in institutional development, supporting cooperative, rather than only competitive, interactions [4]. For example, leading firms have influenced the reform of vocational education laws in Slovakia. This has resulted in the introduction of elements of dual vocational education and training, following leading German and Swiss models. More generally, foreign employers have helped create links with education systems at various levels in the Czech Republic and Hungary, promoting stronger connections between business and academia [4], [5].

\section{What are the limitations of this development?}

The comparative advantage held by the Visegrad countries lies in their institutional complementarities in skilled and cheap labor, foreign capital, and technological innovation brought by transnational companies. However, these factors also underlie the region's main areas of vulnerability. Extreme openness and their relatively small size expose these economies to external shocks and shifts in global demand. Moreover, they are fundamentally dependent on the decisions of transnational firms, leading some observers to dub them "dependent market economies" [2]. Implications of this dependence are manifold.

While the automotive industry is a technologically intensive sector, the Visegrad countries have not fully integrated into most value-added segments of the value chain [1]. This is 
Figure 2. Share of domestic firms in each value-added segment in car manufacturing

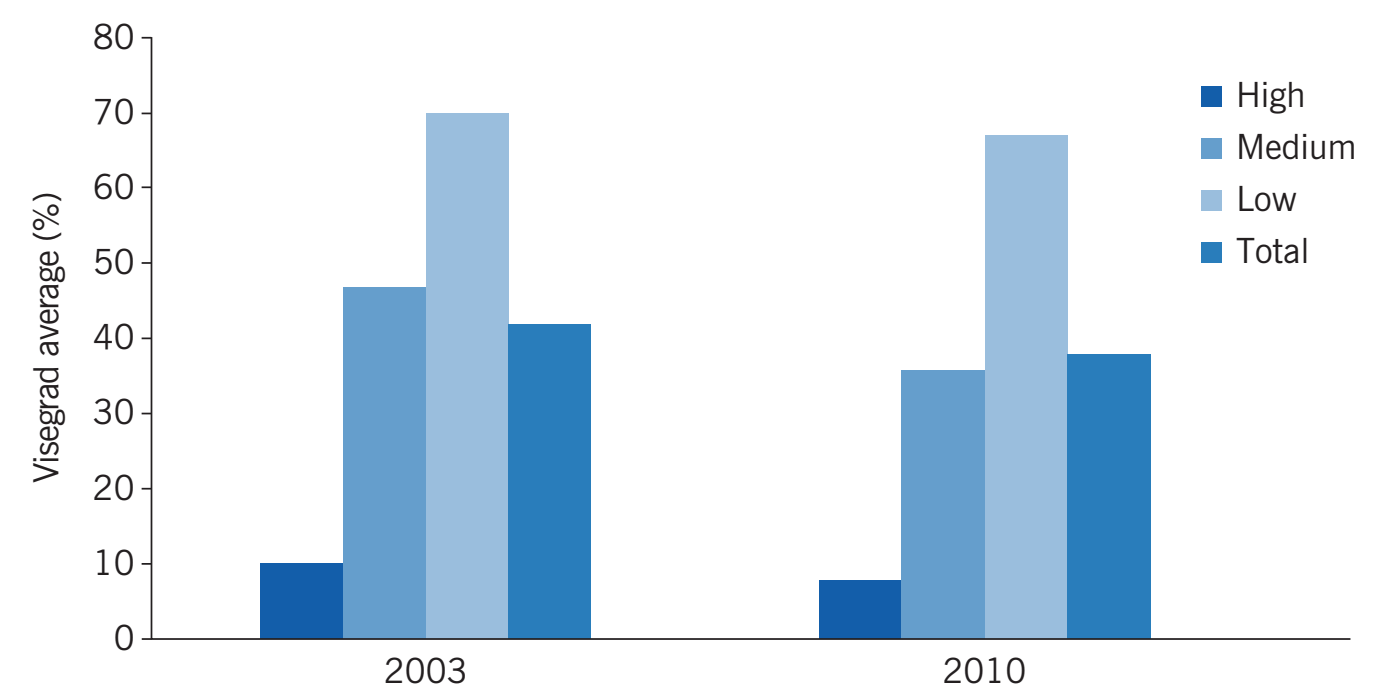

Note: High, medium, and low denote the top, middle, and bottom thirds respectively of the value-added distribution. The Czech Republic, Hungary, Slovakia, and Poland form the Visegrad group of countries.

Source: Based on data from Šćepanović V. "FDI as a solution to the challenges of late development: Catch-up without convergence?" PhD Dissertation, Central European University, 2013 [1].

revealed by the small concentration of domestic firms operating in the highest valueadded segment, with no obvious improvement over time (Figure 2). Furthermore, the share of R\&D in value added and employment remains far below the German, French, or Italian levels, although the Czech Republic performs relatively better than its Visegrad neighbors [1], [5]. Low R\&D intensity signals limited knowledge retention and lesser embedding of companies. This in turn increases the risk of relocation, should the costs of labor increase to uncompetitive levels, as evidenced by various automotive factory closures in Western countries in the past decades [8].

While the automotive industry has contributed to high growth rates and convergence with the rest of the EU, economic development in Visegrad countries has been characterized by large and growing intra-country inequalities (Figure 3) [10], [12]. In effect, growth in the region has not been inclusive. Low-skilled and young people have faced high unemployment rates relative to other EU countries. The Roma population has been kept on the fringes of societies, marginalized and excluded from formal labor markets, even at times of labor shortages. This points to a policy failure, but also marks a broader challenge of bringing complex manufacturing production to underdeveloped regions where infrastructure might be lacking and from where the most educated people have left for other regions or countries. Further economic diversification to include other industries and services might be crucial to achieve a more equal distribution of the economic benefits ensuing from the existing developmental model.

The declining supply of well-trained labor has gradually become one of the key bottlenecks for further expansion and sustainability of manufacturing industries in Visegrad countries. By 2017, firms faced labor and skill shortages in the order of thousands of workers. Policymakers have been troubled by labor market mismatches characterized by the concurrent existence of high unemployment among selected groups and workforce 
Figure 3. GDP per capita as a percentage of the EU average, 2015

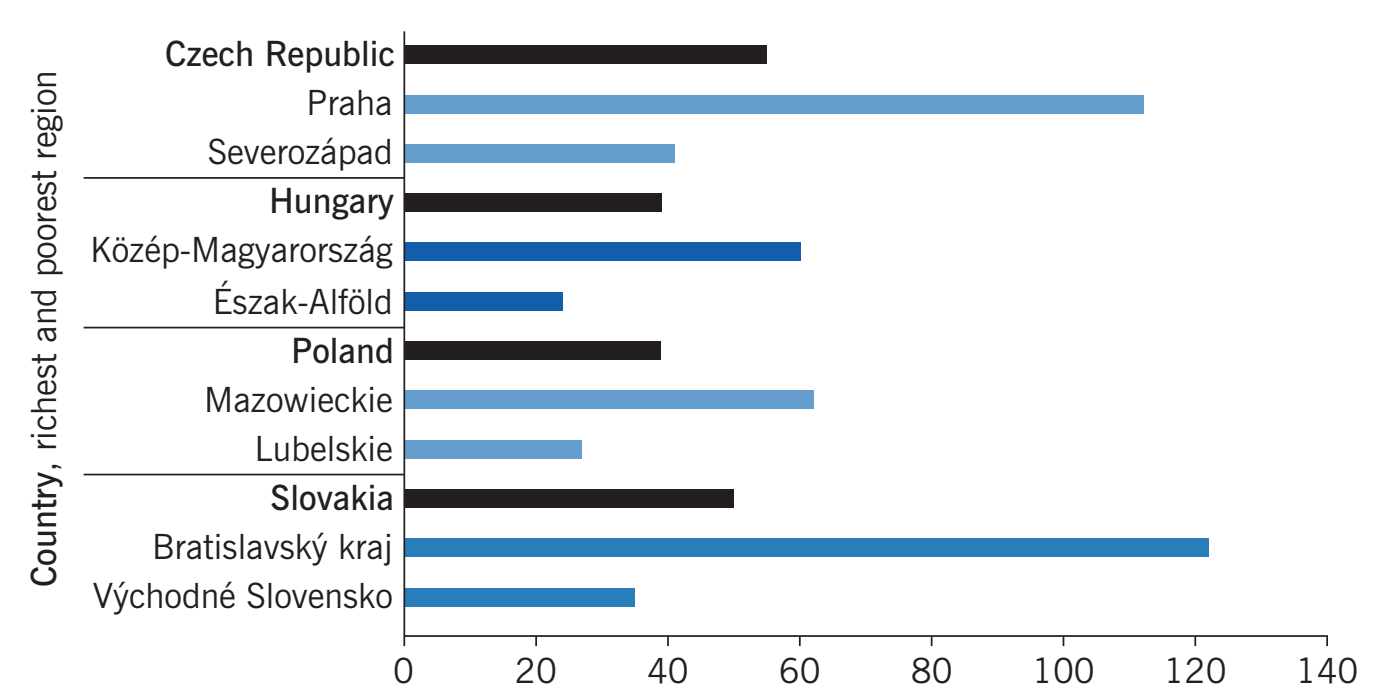

Note: Country names in bold. The Nomenclature of Territorial Units for Statistics (NUTS) is a hierarchical classification of administrative areas for EU countries. NUTS 2 areas are the second largest subdivisions in the system, with populations between 800,000 and 3 million people.

Source: Gross domestic product (GDP) at current market prices by NUTS 2 regions [nama_10r_2gdp], Eurostat. Online at: http://ec.europa.eu/eurostat [downloaded January 22, 2018].

shortages. This is partly due to underperforming education systems, which have only partially adapted to market demands.

The labor market implications of the region's developmental model have also been mixed. Dual labor markets have emerged, characterized by islands of excellent working conditions for companies' core workforces, which mirror Western standards. In parallel, agency workers at the same firms are offered irregular employment, lower wages, and often precarious living conditions [13]. Firms have increasingly relied on an immigrant workforce from countries such as Serbia and Ukraine. However, Visegrad countries continue to promote inward-looking immigration policies and are poor at immigrant integration, which presents barriers to hiring a qualified foreign workforce.

\section{LIMITATIONS AND GAPS}

While broader economic benefits of the Visegrad developmental model have been acknowledged, there is a dearth of rigorous studies that critically evaluate the aggregate impact of spillover effects or that offer a balanced account of the model's costs, benefits, and limitations. There are also few studies that evaluate complex implications of the model, looking at different levels (macro, mezzo, and micro), or from the perspective of different actors: domestic and foreign firms, labor, governments, and other relevant actors, such as social partners.

While much research has gone into understanding the development of the automotive sector, less is known about home-grown internationally competitive firms in other industries (e.g. information and communication technologies) or the role of MNCs in services [1]. Understanding their success or failure parameters could significantly add to knowledge about the broader factors behind particular developmental trajectories 
of post-socialist countries [9]. It would also allow one to derive generalizable lessons for other middle-income countries.

The process of embedding foreign firms is crucial for the sustainability of foreign investments. There is, however, only a limited body of research studying foreign firms' involvement in shaping national frameworks and institutions, how embedding can be supported, and what capacities need to be built in order to equip national players with the knowledge and skills to act as qualified partners in this process.

Finally, more systematic comparative research would be useful in terms of understanding factors beyond national frameworks and how they play out in the dynamic realities of the refugee crisis, Brexit, and other international events that are likely to have strong economic effects on Europe and the Visegrad economies.

\section{SUMMARY AND POLICY ADVICE}

The automotive sector has become a leading industry in Central Europe, placing the Visegrad countries among the top per capita car producers in the world. With the growth of supplier networks and the industry's high skill and technological intensity, its presence yields many benefits to the economy, including spillover effects and the development of positive institutions and governance practices. Such a developmental path, however, faces limitations in the form of regional inequalities, exhaustion of the region's available skilled workforce, and excessive dependence on foreign firms and exports. So far, the $R \& D$ content in employment or value added remains limited, although various forms of upgrading unarguably took place over the past two and a half decades.

Public policy should focus on increasing the share of R\&D in the region, further improving national skill bases and diversifying economic structures to include other industrial sectors and services. This might require a more open immigration policy to bring in a foreign workforce with diverse skill levels. Governments could further benefit from a more thorough understanding of how foreign firms become embedded in a national economy, in order to develop more effective tools to support the upgrading of industries in the region.

Furthermore, policy attention should improve its focus on education systems, which have received less financing relative to Western Europe. Vocational education systems in Central Europe have gone through various reforms, and currently face quality, reputation, and attractiveness issues. A key challenge lies in designing vocational education that is able to endow students with skills that are both specific and transferable. In parallel, it is important to teach high levels of general skills and to invest more in lifelong learning to enable flexible career pathways. Linking secondary and tertiary education closer to the world of production requires governance mechanisms and trust that might be difficult to secure in the region's institutional context, which is defined by weak social dialogue [13].

A key lesson for other countries interested in promoting complex industrial production is that active governmental support might be crucial for attracting foreign capital and for successfully establishing the sector in the global market. This may only be possible if other prerequisite conditions for capital- and skill-intensive industries exist, such as a well-educated workforce, robust physical infrastructure, political stability, and quality institutions. 


\section{Acknowledgments}

The author thanks three anonymous referees and the IZA World of Labor editors for many helpful suggestions on earlier drafts. Previous work of the author contains a larger number of background references for the material presented here and has been used intensively in all major parts of this article [4], [8], [9], [11].

\section{Competing interests}

The IZA World of Labor project is committed to the IZA Guiding Principles of Research Integrity. The author declares to have observed these principles.

@ Lucia Mýtna Kureková 


\section{REFERENCES}

\section{Further reading}

Bryson, J. R., J. Clark, and V. Vanchan (eds). Handbook of Manufacturing Industries in the World Economy. Cheltenham: Edward Elgar Publishing, 2015.

Pavlínek, P. Dependent Growth: Foreign Investment and the Development of the Automotive Industry in EastCentral Europe. New York: Springer, 2017.

\section{Key references}

[1] Šćepanović, V. "FDI as a solution to the challenges of late development: Catch-up without convergence?" PhD Dissertation, Central European University, 2013.

[2] Nölke, A., and A. Vliegenthart. "Enlarging the varieties of capitalism: The emergence of dependent market economies in East Central Europe." World Politics 61:4 (2009): 670-702.

[3] Bohle, D., and B. Greskovits. Capitalist Diversity on Europe's Periphery. Ithaca, NY: Cornell University Press, 2012.

[4] Hancké, B., and L. Kureková. Varieties of Capitalism and Economic Governance in Central Europe. Report for NewGov/STACEE, September 2008.

[5] Pavlínek, P. "The internationalization of corporate R\&D and the automotive industry R\&D of East-Central Europe." Economic Geography 88:3 (2012): 279-310.

[6] Galgóczi, B., J. Drahokoupil, and M. Bernaciak. Foreign Investment in Eastern and Southern Europe after 2008. Still a Lever of Growth? Brussels: ETUI, 2015.

[7] Pavlínek, P., and P. Žížalová. "Linkages and spillovers in global production networks: Firm-level analysis of the Czech automotive industry.” Journal of Economic Geography 16:2 (2016): 331-363.

[8] Jakubiak, M., P. Kolesár, I. Izvorski, and L. Kureková. The Automotive Industry in the Slovak Republic: Recent Developments and Impact on Growth. Commission on Growth and Development Working Paper No. 29, 2008.

[9] Kureková, L. "Success against all odds? Determinants of sectoral rise and decline in Central Europe.” Eastern European Political Society 26:3 (2012): 643-664.

[10] Medve-Bálint, G. "The role of the EU in shaping FDI flows to East Central Europe." Journal of Common Market Studies 52:1 (2014): 35-51.

[11] Duman., A., and L. Kureková. "The role of state in development of socio-economic models in Hungary and Slovakia: The case of industrial policy." Journal of European Public Policy 19:8 (2012): 1207-1228.

[12] Medve-Bálint, G. "Converging on divergence: The political economy of uneven regional development in East Central Europe (1990-2014)." PhD Dissertation, Central European University, 2014.

[13] Drahokoupil, J., M. Myant, and S. Domonkos. "The politics of flexibility: Employment practices in automotive multinationals in Central and Eastern Europe." European Journal of Industrial Relations 21:3 (2015): 223-240.

\section{Online extras}

The full reference list for this article is available from:

https://wol.iza.org/articles/the-automotive-industry-in-central-europe-a-success

View the evidence map for this article:

https://wol.iza.org/articles/the-automotive-industry-in-central-europe-a-success/map 